\title{
SOYBEAN LECITHIN ENHANCED CELLULASE PRODUCTION BY PENICILLIUM OXALICUM JG IN A SCALED-UP BIOCONVERSION PROCESS
}

\author{
XIAORONG GAO, YANG LI and JIAN ZHANG \\ Liaoning Key Laboratory of Molecular Recognition and Imaging, School of Bioengineering, \\ Dalian University of Technology, Dalian, Liaoning, China \\ × Corresponding author: X. Gao, biogaoxr@dlut.edu.cn
}

Received October 15, 2019

The present research focuses on the production of cellulase from Penicillium oxalicum JG by optimizing the bioconversion process parameters and investigates the effects of different surfactants on the submerged fermentation process. Initially, cellulase production in shake flasks resulted in a cellulase activity of $0.22 \mathrm{FPU} / \mathrm{mL}$. The optimization of process parameters increased the cellulase yield 1.7-fold and resulted in maximum cellulase activity of 0.366 FPU/mL within 7 days, with wheat bran and soybean meal selected as carbon source and nitrogen source at an initial $\mathrm{pH}$ of 1.5. Furthermore, the addition of soybean lecithin significantly enhanced cellulase production 2.19-fold and resulted in a maximum cellulase activity of $0.482 \mathrm{FPU} / \mathrm{mL}$. The cellulase production was successfully scaled up to a 5 $\mathrm{L}$ stirred-tank bioreactor, the maximum cellulase activity reached $0.662 \mathrm{FPU} / \mathrm{mL}$, while the addition of the soybean lecithin significantly enhanced the cellulase activity, reaching $1.08 \mathrm{FPU} / \mathrm{mL}$. A similar cellulase titer can be obtained with shortened cultivation time from 7 to 3 days. The addition of low-cost soybean lecithin provides a great potential for its application in cellulase production.

Keywords: cellulase, Penicillium oxalicum JG, lecithin, bioreactor

\section{INTRODUCTION}

As agricultural and forest by-products, biodegradable lignocellulosic wastes from plants contain $40-50 \%$ cellulose and can be regarded as a potentially sustainable carbon source for renewable biofuels. ${ }^{1}$ The key step for the utilization of cellulose is its enzymatic hydrolysis into monomeric sugars and subsequent conversion into valuable fine chemicals and energy. ${ }^{2,3}$ Cellulase is a multi-enzyme complex that is mainly composed of endo-glucanase, exo-glucanase and $\beta$-glucosidase (BGL) acting synergistically during enzymatic hydrolysis. At present, almost all commercially available cellulases are mainly derived from mutant strains of Trichoderma reesei. However, the lower ratio between BGL activity and filter paper cellulase (FPase) activity of $T$. reesei results in feedback inhibition from higher accumulation of cellobiose during hydrolysis. Also, T. reesei might have obvious disadvantages on some important parameters, such as protein production level and cellulase hydrolytic performance per unit of activity or milligram of protein. ${ }^{4,5}$ Therefore, other filamentous fungi, including Penicillium, Aspergillus, Chrysosporium and Acremonium species, have been tested as alternatives to $T$. reesei for the production of cellulases. ${ }^{6}$ Several strains of Penicillium spp. have been reported to produce a better cellulase titer, higher BGL/FPA (FPase activity), and other necessary enzymatic activities. $^{7}$

To enhance enzyme production and decrease the cost of bioconversion, the process parameters should be optimized for achieving a maximal enzyme-producing potential. The response surface methodology (RSM) method has been successfully employed for optimizing bioprocess parameters to enhance enzymatic hydrolysis, enzyme production etc. ${ }^{8,9}$ Surfactants also have a wide range of applications for research and for the industrial production of cellulases. ${ }^{10-12}$ They can enhance cellulose degradation and improve the 
efficiency of cellulase production and stability. ${ }^{13-15}$ However, most chemically synthesized surfactants, such as Tween-20, Tween-80, Triton X-100 and polyethylene glycol (PEG), are not biodegradable. Biosurfactant rhamnolipid can noticeably increase cellulase production and activities, but its high cost limits its application. ${ }^{16,17}$ Lecithin is a natural biodegradable surfactant and additive, which has the advantages of amphiphilicity, low toxicity and low cost. It is widely used in the food and pharmaceutical industries, ${ }^{18}$ but little information is available on its application for large-scale cellulase production.

In addition, even though cellulase is critical for cellulose degradation, its utilization might be restricted because of the high crystallinity of the cellulose structure, its compactness, insolubility in water and lack of adsorption to cellulase. At an industrial level, the cellulose substrate is usually pretreated by acid-base or steam explosion methods to make the structure loose and dispersed. This study optimized the fermentation process parameters with regard to growth substrates and initial $\mathrm{pH}$ using RSM, and discussed the influences of surfactant addition and acidification pretreatment on the enzyme production. The optimized process of cellulase production was further tested in a scaled-up bioreactor.

\section{EXPERIMENTAL}

\section{Fungal strain and culture conditions}

Penicillium oxalicum JG was maintained and sub-cultured on potato dextrose (PDA) plates (agar 20 $\mathrm{g} / \mathrm{L})$ at $28 \pm 1{ }^{\circ} \mathrm{C}$ and the culture sporulated fully after 5 days. ${ }^{19}$ Spores were obtained by dislodging them from the surface of fully grown Penicillium oxalicum JG using a PDA slant into sterile $0.05 \%$ Tween-80 solution. Spores were counted on a haemocytometer and $10^{8}$ spores $/ 100 \mathrm{~mL}$ were inoculated into the shake flasks for enzyme production.

Analytical grade polyethylene glycol (PEG), rhamnolipid and soybean lecithin were purchased from J\&K Scientific Ltd. (China).

\section{Enzyme production in shake flasks}

The medium used for initial shake-flask fermentation was composed of (per litre): $30 \mathrm{~g}$ of wheat bran, $3 \mathrm{~g}$ of soybean meal, $2 \mathrm{~g}$ of $\mathrm{KCl}, 2 \mathrm{~g}$ of $\mathrm{KH}_{2} \mathrm{PO}_{4}$. Enzyme production was carried out in 250 -mL Erlenmeyer flasks, which were incubated at 28 ${ }^{\circ} \mathrm{C}$ under shaking at $200 \mathrm{rpm}$ for 7 days.

\section{Enzyme activity assay}

FPase activity (FPA) was assayed by incubating the diluted enzyme $(0.2 \mathrm{~mL})$ with $1.8 \mathrm{~mL}$ HAc-NaAc buffer (0.1 M, pH 4.8), containing Whatman No. 1 filter paper $(50 \mathrm{mg}, 1 \times 6 \mathrm{~cm})$. The reaction mixture was incubated at $50{ }^{\circ} \mathrm{C}$ for $60 \mathrm{~min}$. BGL activity was estimated using PNPG ( $p$-nitrophenyl-D-glucopyranoside) as substrate. The total of the assay mixture $(1 \mathrm{~mL})$, consisting of $0.8 \mathrm{~mL}$ of PNPG $(1 \mathrm{mg} / \mathrm{mL})$ and $0.2 \mathrm{~mL}$ of suitably diluted enzyme, was incubated at $50{ }^{\circ} \mathrm{C}$ for $30 \mathrm{~min}$. The p-nitrophenol liberated was measured at $410 \mathrm{~nm}$ after adding $2 \mathrm{~mL}$ of sodium carbonate $(2 \%)$. The total reducing sugars as glucose equivalents were analyzed by the 3,5-dinitrosalicylic acid method, as described by Miller (1959). ${ }^{20}$

One unit (IU) of enzyme activity was defined as the amount of enzyme required to liberate $1 \mu \mathrm{mol}$ of glucose or p-nitrophenol produced from the appropriate substrates per min of crude filtrate under standard assay conditions.

\section{Statistical optimization of conditions for cellulase production using RSM}

The second order Box-Behnken design (BBD) was employed for optimizing the conditions for cellulase production. $^{21}$ The concentrations of wheat bran $(\%$, $\mathrm{w} / \mathrm{v})$ and soybean meal $(\%, \mathrm{w} / \mathrm{v})$ and the initial $\mathrm{pH}$ were selected as independent variables at three different levels based on the results of the single-factor analysis method (not shown). Design-Expert software version 8.0 (Stat Ease Inc., Minneapolis, MN, USA) was used to build and analyze the experimental design by subjecting the data to the analysis of variance (ANOVA), determining the estimated effects and interactions, and fitting the regression equation to the data, as described by Saini et al. ${ }^{22}$ A second-order polynomial (Eq. (1)) was used to describe the effects of variables on the response:

$\mathrm{Y}_{1}=\mathrm{b}_{0}+\mathrm{b}_{1} \mathrm{~A}+\mathrm{b}_{2} \mathrm{~B}+\mathrm{b}_{3} \mathrm{C}+\mathrm{b}_{11} \mathrm{~A}_{2}+\mathrm{b}_{22} \mathrm{~B}_{2}+\mathrm{b}_{33} \mathrm{C}_{2}+\mathrm{b}_{12} \mathrm{AB}+$ $\mathrm{b}_{13} \mathrm{AC}+\mathrm{b}_{23} \mathrm{BC}$

where $Y_{1}$ is the response variable, $b_{0}$ is a constant term, $b_{1}, b_{2}$ and $b_{3}$ are the monomial coefficients; $b_{11}, b_{22}$ and $b_{33}$ are the squared coefficients; $b_{12}, b_{13}$ and $b_{23}$ are the interaction coefficients.

\section{Surfactant addition tests}

For investigating the effect of surfactant addition on enzyme production, several surfactants, including EDTA-2Na (2 g/L), SDS (2 g/L), PEG (5 g/L), rhamnolipid $(1 \mathrm{~g} / \mathrm{L})$ and lecithin $(5 \mathrm{~g} / \mathrm{L})$, were added to the optimized medium. Enzyme production was carried out in $250-\mathrm{mL}$ Erlenmeyer flasks, which were incubated at $28{ }^{\circ} \mathrm{C}$ under shaking at $200 \mathrm{rpm}$ for 7 days.

\section{Pretreatment of wheat bran}

The pretreatment of cellulose is one of the most important factors that affect the catalytic efficiency of cellulase. Therefore, wheat bran was pretreated with 12 $\mathrm{g} / \mathrm{L}$ lecithin and $12 \mathrm{~g} / \mathrm{L}$ lecithin with muriatic acid for 3 
hours. Then, the flasks were incubated at different temperatures $\left(28{ }^{\circ} \mathrm{C}, 36^{\circ} \mathrm{C}, 40{ }^{\circ} \mathrm{C}\right)$, separately, under shaking at $200 \mathrm{rpm}$ for 144 hours, for determining the optimum temperature of the hydrolysis process. Each FPA and the total reducing sugars were assayed.

\section{Enzyme production in a 5-L stirred-tank bioreactor}

The medium used for enzyme production in a $5-\mathrm{L}$ stirred-tank bioreactor (HG-1010-5L, Beijing Baiwan Electronic Technology, China) had a similar composition, as described above. Sterilization of the bioreactor vessel with enzyme production medium was performed in an autoclave at $121{ }^{\circ} \mathrm{C}$ for $30 \mathrm{~min}$. The temperature was maintained at $28{ }^{\circ} \mathrm{C}$, and the $\mathrm{pH}$ was controlled at 2.0 by addition of $1 \mathrm{M} \mathrm{HCl}$ or $1 \mathrm{M} \mathrm{NaOH}$. Spores were cultivated in seed medium for $48 \mathrm{~h}$, and inoculated into the fermentation broth at the rate of $10^{9}$ spores/L and airflow of $1 \mathrm{vvm}$. Pitch blade impellers were used to maintain an agitation speed of 200 . Antifoam (2\%, v/v) was autoclaved separately and approximately $0.5 \mathrm{~mL}$ was added manually during frothing. Sampling was performed every $12 \mathrm{~h}$ for analysis of cellulase activities. Extracellular enzyme was extracted by centrifugation of the sample at 8000 rpm for $10 \mathrm{~min}$.

\section{RESULTS AND DISCUSSION}

Statistical optimization of cellulase production under submerged fermentation (SmF) using RSM

Penicillium oxalicum JG initially produced maximum FPA of $0.22 \mathrm{FPU} / \mathrm{mL}$. Considering the cellulase activities need to be enhanced further for biofuel applications, RSM was adopted for further optimization at a shake flask level for improving the cellulase enzyme production. Design Expert (version 8.0) was employed for designing the experimental layout with a total of 17 experiments according to the Box-Behnken design (BBD), with three different variables at three different levels, namely, lower, middle and upper $(-1,0$, $+1)$. Table 1 shows the different independent variables and the cellulase activity $(\mathrm{FPU} / \mathrm{mL}$ ) responses. The data obtained from the $\mathrm{BBD}$ matrix yielded the following regression equation (Eq. (2)), which represents the empirical relationship between cellulase activity (FPU/mL) and the significant test variables in coded form:

$\mathrm{Y}=+0.31+0.05 \mathrm{~A}+8.750 \times 10^{-3} \mathrm{~B}-0.011 \mathrm{C}-$ $0.018 \mathrm{AB}+0.015 \mathrm{AC}+1.000 \times 10^{-3} \mathrm{BC}-0.048 \mathrm{~A}^{2}-$ $0.028 \mathrm{~B}^{2}-2.550 \times 10^{-3} \mathrm{C}^{2}$

where the coded variables were: $\mathrm{Y}=$ cellulase activity $(\mathrm{FPU} / \mathrm{mL}) ; \mathrm{A}=$ wheat bran concentration $(\%, \mathrm{w} / \mathrm{v}) ; \mathrm{B}=$ soybean meal concentration $(\%$, $\mathrm{w} / \mathrm{v})$ and $\mathrm{C}=\mathrm{pH}$.
The results for cellulase production predicted by the Design Expert software were fitted to a second-order model. The model was found 'significant' with $\mathrm{P}$ value $<0.0001$ and a 'non-significant' lack of fit value (Table 2). ANOVA of the model for cellulase production showed validity of the predictions in terms of p-value $(<0.0001)$ and the coefficient of determination (R2) value of 0.9805 , the adjustment coefficient (adjusted R2) of 0.9554 . Contour plots for cellulase (FPU/mL) production were generated by using the coefficients of the polynomial equation. In this case, factors $\mathrm{A}$ (wheat bran concentration), B (soybean meal concentration), and $\mathrm{C}(\mathrm{pH})$ and the interactions between $\mathrm{AB}$ and $\mathrm{AC}$ were significant model terms.

Three-dimensional response surfaces (Fig. 1) were plotted for each dependent variable, considering the interaction between two most important independent variables. Figure 1a shows the interaction of wheat bran concentration and soybean meal concentration to the cellulase (FPU/mL). At a certain $\mathrm{pH}$, cellulase $(\mathrm{FPU} / \mathrm{mL})$ increased with increasing concentration of wheat bran up to $45-48 \mathrm{~g} / \mathrm{L}$, then a downward trend occurred with higher concentration of wheat bran. The concentrations of wheat bran and soybean meal determine the $\mathrm{C} / \mathrm{N}$ ratio of the medium, which affects strain growth and enzyme production. Figure $1 \mathrm{~b}$ depicts the interaction of wheat bran concentration and $\mathrm{pH}$. Cellulase production increased with increasing concentration of wheat bran at lower $\mathrm{pH}$ (Fig. 1b), but the interactions between soybean meal concentration and $\mathrm{pH}$ have less effect on the response values (result was not given). Based on the ANOVA analysis, the influence of the above three factors on the response values was as follows: A (carbon source) $>\mathrm{C}(\mathrm{pH})>\mathrm{B}$ (nitrogen source). Therefore, the optimal culture conditions for maximum cellulase production of 0.384 FPU/mL were predicted as: $46.9 \mathrm{~g} / \mathrm{L}$ wheat bran and $6.33 \mathrm{~g} / \mathrm{L}$ soybean meal and initial fermentation $\mathrm{pH}$ of 1.5 with $2.0 \mathrm{~g} / \mathrm{L} \mathrm{KH}_{2} \mathrm{PO}_{4}$ and $2.0 \mathrm{~g} / \mathrm{L} \mathrm{KCl}$. Furthermore, BGL activity increased by $1.08 \mathrm{IU} / \mathrm{mL}$, while it was $0.806 \mathrm{IU} / \mathrm{mL}$ initially. Several strains of Penicillium spp. have been reported to produce comparable or even better cellulase titer, along with higher BGL, as well as other necessary enzyme activities. ${ }^{23}$ The validation experiment performed in a shake flask under these conditions resulted in cellulase activity of $0.366 \mathrm{FPU} / \mathrm{mL}$ in 7 days. It represented 
a 1.7-fold increase in cellulase enzyme activity when compared to the cellulase production under non-optimized conditions. Previous studies reported that process optimization resulted in 4.7-fold enhanced cellulase activities from $T$. reesei RUT C-30 in solid state fermentation and 1.6-fold (84\%) enhanced cellulase activities from Penicillium sp. CLF-S. ${ }^{24,25}$ This proved an overall good agreement between the experimentally determined (observed) response and the optimum response predicted through the model.

Table 1

Three level Box-Behnken design and the experimental response of dependent variable cellulase activity (FPU/mL) of $P$. oxalicum $\mathrm{JG}^{*}$

\begin{tabular}{ccccc}
\hline $\begin{array}{c}\text { Run } \\
\text { no. }\end{array}$ & $\begin{array}{c}\text { Wheat bran } \\
\text { concentration } \\
(\mathrm{g} / \mathrm{L})\end{array}$ & $\begin{array}{c}\text { Soybean meal } \\
\text { concentration } \\
(\mathrm{g} / \mathrm{L})\end{array}$ & $\mathrm{pH}$ & $\begin{array}{c}\text { Cellulase } \\
\text { activity } \\
(\text { FPU/mL) }\end{array}$ \\
\hline 1 & $42(0)$ & $6(0)$ & $2.25(0)$ & 0.311 \\
2 & $42(0)$ & $6(0)$ & $2.25(0)$ & 0.310 \\
3 & $42(0)$ & $8(1)$ & $1.50(-1)$ & 0.295 \\
4 & $42(0)$ & $6(0)$ & $2.25(0)$ & 0.300 \\
5 & $28(-1)$ & $8(1)$ & $2.25(0)$ & 0.209 \\
6 & $28(-1)$ & $6(0)$ & $3.00(1)$ & 0.176 \\
7 & $28(-1)$ & $4(-1)$ & $2.25(0)$ & 0.163 \\
8 & $42(0)$ & $4(-1)$ & $3.00(1)$ & 0.263 \\
9 & $42(0)$ & $8(1)$ & $2.25(0)$ & 0.290 \\
10 & $56(1)$ & $8(1)$ & $2.25(0)$ & 0.271 \\
11 & $42(0)$ & $4(-1)$ & $1.50(-1)$ & 0.272 \\
12 & $56(1)$ & $4(-1)$ & $2.25(0)$ & 0.297 \\
13 & $56(1)$ & $6(0)$ & $3.00(1)$ & 0.309 \\
14 & $56(1)$ & $6(0)$ & $1.50(-1)$ & 0.315 \\
15 & $42(0)$ & $6(0)$ & $2.25(0)$ & 0.320 \\
16 & $28(-1)$ & $6(0)$ & $1.50(-1)$ & 0.242 \\
17 & $42(0)$ & $6(0)$ & $2.25(0)$ & 0.312 \\
\hline
\end{tabular}

Experimental cellulase activity (FPU/mL) is the mean of triplicate experiments;

*Values in parentheses represent the levels of independent variables in coded form

Table 2

ANOVA for response surface quadratic model for cellulase production using P. oxalicum JG

\begin{tabular}{lccccc}
\hline Source & $\begin{array}{c}\text { Sum of } \\
\text { squares }\end{array}$ & $\begin{array}{c}\text { Degree of } \\
\text { freedom }(\mathrm{df})\end{array}$ & $\begin{array}{c}\text { Mean } \\
\text { square }\end{array}$ & F-value & $\begin{array}{c}\text { P-value } \\
\text { Prob }>\mathrm{F}\end{array}$ \\
\hline Model & 0.03800 & 9 & 0.0041 & 39.05 & $<0.0001^{* *}$ \\
$\mathrm{~A}$ & 0.02000 & 1 & 0.0200 & 188.87 & $<0.0001^{* *}$ \\
$\mathrm{~B}$ & 0.00061 & 1 & 0.0006 & 5.73 & $0.0480^{*}$ \\
$\mathrm{C}$ & 0.00092 & 1 & 0.0009 & 8.64 & $0.0217^{*}$ \\
$\mathrm{AB}$ & 0.00129 & 1 & 0.0013 & 12.12 & $0.0103^{*}$ \\
$\mathrm{AC}$ & 0.00090 & 1 & 0.0009 & 8.41 & $0.0230^{*}$ \\
$\mathrm{~A}^{2}$ & 0.00952 & 1 & 0.0095 & 89.01 & $0.0001^{*}$ \\
$\mathrm{~B}^{2}$ & 0.00331 & 1 & 0.0033 & 30.97 & $0.0008^{*}$ \\
Residual & 0.00074 & 7 & 0.0001 & & \\
Lack of fit & 0.00005 & 3 & 0.0001 & 3.58 & 0.1249 \\
Pure error & 0.0002032 & 4 & 0.0000 & & \\
Total & 0.38 & 16 & 5 & & \\
\hline
\end{tabular}

Values of "Prob > F" less than 0.0500 indicate model terms are significant; *significant; **highly significant 
Table 3

Effect of surfactant on cellulase activity by P. oxalicum JG

\begin{tabular}{lcc}
\hline Surfactants & $\begin{array}{c}\text { FPA } \\
(\text { FPU/mL) }\end{array}$ & $\begin{array}{c}\text { BGL activity } \\
(\mathrm{IU} / \mathrm{mL})\end{array}$ \\
\hline Not added & $0.366 \pm 0.017$ & $1.081 \pm 0.012$ \\
EDTA-2Na & $0.167 \pm 0.011$ & $0.218 \pm 0.009$ \\
SDS & $0.181 \pm 0.020$ & $0.436 \pm 0.018$ \\
PEG & $0.396 \pm 0.009$ & $0.982 \pm 0.010$ \\
Lecithin & $0.482 \pm 0.021$ & $1.197 \pm 0.015$ \\
Rhamnolipid & $0.464 \pm 0.014$ & $1.243 \pm 0.020$ \\
\hline
\end{tabular}

Results are presented as the mean $(n=3) \pm S D$
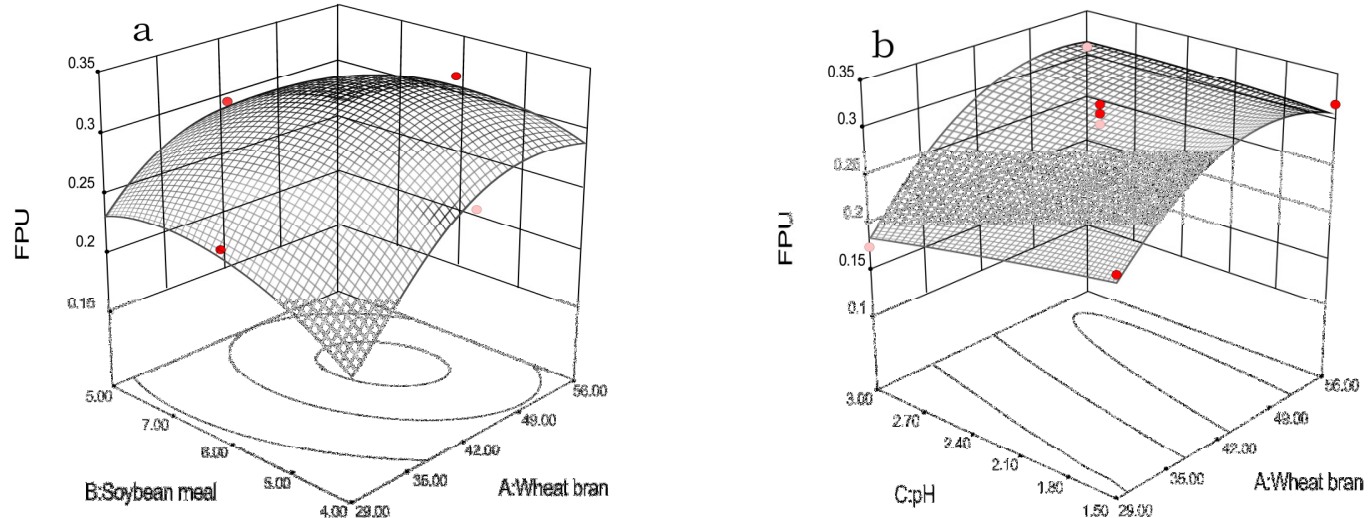

Figure 1: Three-dimensional response surface plots showing (a) the effect of wheat bran and soybean meal concentration and (b) the effect of wheat bran and initial $\mathrm{pH}$ on cellulase production (FPU/mL) by $P$. oxalicum JG under submerged fermentation (other factors in the plots were at their respective middle levels)

\section{Lecithin addition effect on cellulase production}

The addition of each surfactant, including EDTA-2Na, SDS, PEG, rhamnolipid and lecithin, showed diverse effects on the cellulase production from Penicillium oxalicum JG (Table 3). The EDTA-2Na and SDS additions showed obvious inhibitory effects on FPA and BGL activity, while PEG addition performed a promoting effect on FPA. As expected, it was concluded in this study that rhamnolipid promoted the cellulase production to the maximal value of 0.464 FPU/mL, while BGL activity increased by 1.243 $\mathrm{IU} / \mathrm{mL}$. This is consistent with the observations from several previous studies that rhamnolipid promotes the cellulase activities. ${ }^{26,27}$ Wang et al. also observed that the stimulatory effects of rhamnolipid are superior to those of Triton X-100 on cellulase activities from Penicillium expansum. ${ }^{28}$ It must also be mentioned that soybean lecithin addition increased the FPA to its highest observed value of $0.482 \mathrm{FPU} / \mathrm{mL}$, which was $33.3 \%$ higher than the optimized RSM value and $119 \%$ higher than basal medium, BGL activity also increased by $10.7 \%$ (1.197 IU/mL).
Lecithin is also a zwitterionic biosurfactant; J. W. Park noted that cellulase can easily combine with the functional groups of amphiphilic substances to improve the enzyme stability and solubility. ${ }^{29}$ Considering a series of advantages of lecithin, such as its low cost, accessibility and purity, the addition of lecithin has promising potential for application in the industrial production of cellulase by $P$. oxalicum.

\section{Efficiency of pretreatment with lecithin addition on the reducing sugar production}

Previous data have shown that the physicochemical pretreatment of cellulose is beneficial to cellulase production. ${ }^{30}$ Acidic conditions can promote the combination of surfactant with the substrate and improve the efficiency of degradation, thus further improving the enzyme activity. ${ }^{31}$ Pretreatment of wheat brans with soybean lecithin under acidic and non-acidic conditions was carried out, using only the addition of soybean lecithin as control. As shown in Figure 2a, the yield of reducing sugar produced by wheat bran with acidic pretreatment was about 

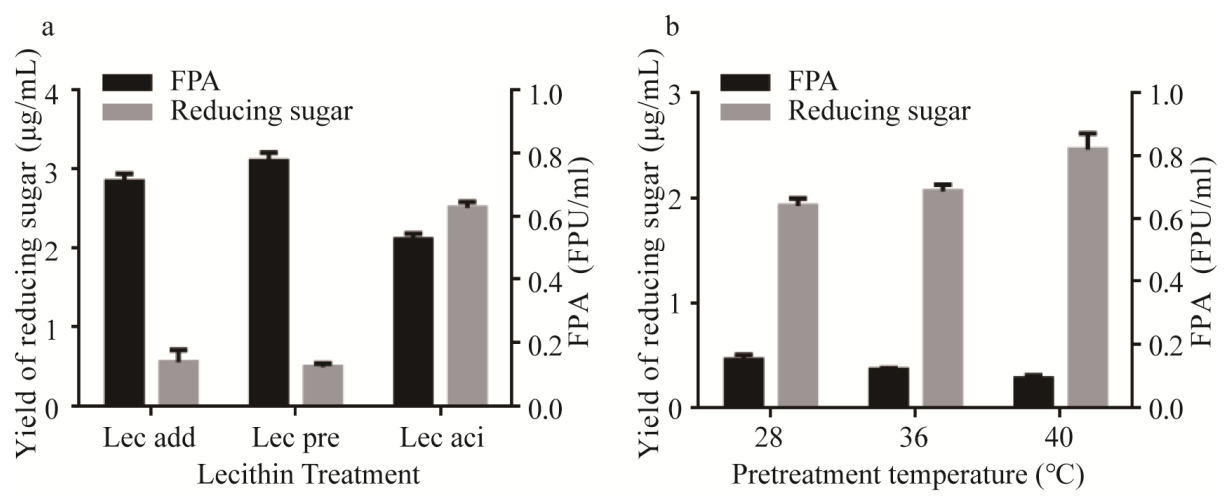

Figure 2: Effect of pretreatments on wheat bran cellulose degradation; a) effect of lecithin treatment (Lec add: lecithin addition, Lec pre: lecithin pretreatment, Lec aci: lecithin acidic pretreatment), b) effect of pretreatment temperature

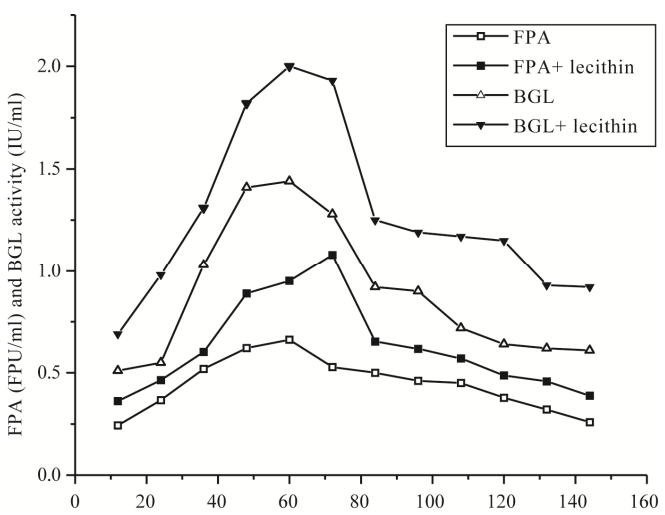

Figure 3: Cellulase production by $P$. oxalicum $\mathrm{JG}$ in a bioreactor under optimized conditions (enzyme activity after adding lecithin)

The reason might be that the acidification pretreatment can loosen the structure of cellulose molecules, so that the surfactant enables the cellulase to approach the surface of the cellulose molecule, then adapts to perform the degradation function, and increases the yield of reducing sugar. However, the repressive effect of reducing sugar products results in lower cellulase activity.

The effect of pretreatment temperature was also studied by performing the pretreatment of wheat bran with lecithin at $28{ }^{\circ} \mathrm{C}, 36{ }^{\circ} \mathrm{C}$ and 40 ${ }^{\circ} \mathrm{C}$ for $3 \mathrm{~h}$, followed by the reducing sugar assay. The production of reducing sugar increased gradually with increasing temperature. The maximum yield of reducing sugar $(2.78 \mu \mathrm{g} / \mathrm{mL})$ was observed at $40{ }^{\circ} \mathrm{C}$, but the enzymatic activities declined gradually because of the repression from glucose production (Fig. 2b).

\section{Cellulase production in a bioreactor}

Penicillium oxalicum is a highly aerobic filamentous fungus, and a bioreactor can better supply the desired $\mathrm{pH}$ and dissolved oxygen requirements for Penicillium growth. Therefore, based on the RSM-optimized liquid fermentation, a combination of pretreatments of wheat bran, with or without the addition of soybean lecithin, was used for scaled-up fermentation in a 5-L stirred-tank bioreactor. Figure 3 shows that FPA started increasing after $12 \mathrm{~h}$, the maximum value of $1.08 \mathrm{FPU} / \mathrm{mL}$ was reached at $72 \mathrm{~h}$ with soybean lecithin addition, while without soybean lecithin addition, the value of $0.662 \mathrm{FPU} / \mathrm{mL}$ was obtained. This fermentation is significantly higher and faster than the cellulase activity of 0.35 FPU/mL reported for $P$. funiculosum with the duration of $170-230 \mathrm{~h}$ for optimum enzyme 
production. ${ }^{32}$ The cellulase activities obtained in this study were higher than those reported recently for $P$. pinophilum $(0.18 \mathrm{FPU} / \mathrm{mL}), C$. cubensis $(0.39 \mathrm{FPU} / \mathrm{mL})$ and A. awamori $(0.42$ FPU/mL). ${ }^{33,34}$ BGL activities also started increasing after $12 \mathrm{~h}$ and continued till $60 \mathrm{~h}$, reaching a maximum of $2.00 \mathrm{IU} / \mathrm{mL}$ with soybean lecithin addition, and a value of $1.441 \mathrm{IU} / \mathrm{mL}$ without soybean lecithin. Therefore, adding lecithin can obviously improve cellulase production. Moreover, the use of a reactor revealed a decrease in incubation time from $144 \mathrm{~h}$ in shaking flasks to $60-72 \mathrm{~h}$ to obtain similar cellulase enzyme titers. Even so, there is room for improvement in the enzyme yields, comparable to previous reports of $4.5 \mathrm{FPU} / \mathrm{mL}$, employing a mutant strain $P$. janthinellum EMS-UV-8. ${ }^{35}$

Compared with the optimized shake flask fermentation, with soybean lecithin addition, the maximum FPA and BGL increased by $224 \%$ and $160 \%$, respectively. However, the value of cellulase activity began to drop after $72 \mathrm{~h}$ of submerged fermentation, and the rapid enzyme production led to a shortage of the lignocellulose substrate; the alternative process of continuous feeding remains a subject for further exploration. Future work will also focus on enhancing the BGL/FPA ratio to reduce enzyme inhibition caused by lesser cellobiose accumulation during hydrolysis.

\section{CONCLUSION}

Soybean lecithin proved its efficiency in cellulase production by $P$. oxalicum JG. When scaled-up to a $5 \mathrm{~L}$ stirred-tank bioreactor, the addition of soybean lecithin significantly enhanced the cellulase production 4.9-fold, while reducing the incubation time from 7 to 3 days to obtain similar cellulase enzyme titers. As an inexpensive, accessible and biodegradable additive, soybean lecithin appears to be lucrative by further optimizing the culture and nutritional parameters to improve the cellulase production. Therefore, the soybean lecithin proves to be a good candidate for biomass hydrolysis for bioethanol applications.

ACKNOWLEDGMENTS: The authors would like to acknowledge the financial support from Grant No. 31200084 given for this work by the National Natural Science Foundation of China, and all the participating experts. The authors also acknowledge the School of Bioengineering, Dalian University of Technology.

\section{REFERENCES}

1 C. A. Cardona and Ó. J. Sanchez, Bioresour. Technol., 98, $\quad 2415 \quad$ (2007), https://doi.org/10.1016/j.biortech.2007.01.002

2 R. P. Ratti, L. S. Botta, I. K. Sakamoto, E. L. Silva and M. B. A. Varesche, Biotechnol. Lett., 36, 537 (2014), https://doi.org/10.1007/s10529-013-1395-z

S. Kim, J. M. Park, J. W. Seo and C. H. Kim, Bioresour. Technol., 109, $229 \quad$ (2012), https://doi.org/10.1016/j.biortech.2012.01.036

4 D. Martinez, R. M. Berka, B. Henrissat, M. Saloheimo, M. Arvas et al., Nat. Biotechnol., 26, 1193 (2008), https://doi.org/10.1038/nbt1008-1193a

5 R. Saini, J. K. Saini, M. Adsul, A. K. Patel, A. Mathur et al., Bioresour. Technol., 188, 240 (2015), https://doi.org/10.1016/j.biortech.2015.01.048

6 A. V. Gusakov, Biofuels, 4, 567 (2014), https://doi.org/10.4155/bfs.13.55

7 H. Zhang, Q. Sang and W. Zhang, Ann. Microbiol., 62 , 629

(2012),

https://doi.org/10.1007/s13213-011-0300-z

8 N. Weiss, J. Börjesson, L. S. Pedersen and A. S. Meyer, Biotechnol. Biofuels., 6, 5 (2013), https://doi.org/10.1186/1754-6834-6-5

9 K. Singh, K. Richa, H. Bose, L. Karthik, G. Kumar et al., 3 Biotech., 4, 591 (2014), https://doi.org/10.1007/s13205-013-0173-x

10 Y. A. Chen, Y. Zhou, Y. Qin, D. Liu and X. Zhao, Bioresour. Technol., 269, $329 \quad$ (2018), https://doi.org/10.1016/j.biortech.2018.08.119

11 P. X. Li, K. Ma, R. K. Thomas and J. Penfold, J. Phys. Chem. B., 120, $3677 \quad$ (2016), https://doi.org/10.1021/acs.jpcb.6b00762

12 A. Boyce and G. Walsh, Appl. Microbiol. Biot., 99, 7515

(2015), https://doi.org/10.1007/s00253-015-6474-8

13 T. Eriksson, J. Börjesson and F. Tjerneld, Enzyme Microb. Technol., 31, $353 \quad$ (2002), https://doi.org/10.1016/S0141-0229(02)00134-5

14 H. Lou, M. Zeng, Q. Hu, C. Cai, X. Lin et al., Bioresour. Technol., 249, 1 (2018), https://doi.org/10.1016/j.biortech.2017.07.066

15 M. H. Yang, A. M. Zhang, B. B. Liu, W. L. Li and J. M. Xing, Biochem. Eng. J., 56, 125 (2012), https://doi.org/10.1016/j.bej.2011.04.009

16 G. M. Zeng, J. G. Shi, X. Z. Yuan, J. Liu, Z. B. Zhang et al., Enzyme Microb. Technol., 39, 1451 (2006), https://doi.org/10.1016/j.enzmictec.2006.03.035

17 M. G. Brondi, V. M. Vasconcellos, R. C. Giordano and C. S. Farinas, Appl. Biochem. Biotech., 187, 461 (2019), https://doi.org/10.1007/s12010-018-2834-z

18 X. Zhan, C. Cai, Y. Pang, F. Qin, H. Lou et al., Bioresour. Technol., 283, $112 \quad$ (2019), https://doi.org/10.1016/j.biortech.2019.03.026 
19 Y. Li, X. R. Gao and J. Zhang, Biotechnol. Bull., 32, 2 (2016), http://www.cnki.net/kcms/doi/10.13560/j.cnki.biotech. bull.1985.2016.02.020

20 G. L. Miller, Anal. Chem., 31, 426 (1959), http://dx.doi.org/10.1021/ac60147a030

21 K. Richa, H. Bose, A. Singh, K. Loganathan, G. Kumar et al., Res. J. Biotechnol., 8, 78 (2013), https://www.researchgate.net/publication/235970119

22 J. K. Sainia, R. K. Anurag, A. Arya, B. K. Kumbhar and L. Tewari, Ind. Crop. Prod., 44, 211 (2013), https://doi.org/10.1016/j.indcrop.2012.11.011

23 R. Saini, J. K. Saini, M. Adsul, A. K. Patel, A. Mathur et al., Bioresour. Technol., 188, 240 (2015), https://doi.org/10.1016/j.biortech.2015.01.048

24 N. K. Mekala, R. R. Singhania, R. K. Sukumaran and A. Pandey, Appl. Biochem. Biotech., 151, 122 (2008), http://dx.doi.org/10.1007/s12010-008-8156-9

25 M. Yang, D. D. Fan, Y. E. Luo, Y. Mi, J. Hui et al., Energ. Source Part A, 34, 1883 (2012), http://dx.doi.org/10.1080/ 15567031003645577

26 P. J. Li, J. L. Xia, Y. Shan, Z. Y. Nie and D. L. Su, Waste. Biomass Valorif., 6, $13 \quad$ (2015), https://doi.org/10.1007/s12649-014-9317-4

27 C. N. Long, Y. Q. Ou, P. Guo, Y. T. Liu, J. J. Cui et al., Ann. Microbiol., 62, $895 \quad$ (2012), http://dx.doi.org/10.1007/BF03175140
28 H. Y. Wang, B. Q. Fan, C. H. Li, S. Liu and M. Lia, Bioresour. Technol., 102, $6515 \quad$ (2001), https://doi.org/10.1016/j.biortech.2011.02.102

29 J. W. Park, Korean J. Chem. Eng., 12, 523 (1995), https://doi.org/10.1007/BF02705854

30 Y. F. He, Y. Z. Pang, Y. P. Liu, X. L. Li and K. S. Wang, Energ. Fuels, 22, 2775 (2008), https://doi.org/10.1021/ef8000967

31 Y. Zhou, H. M. Chen, F. Qi, X. B. Zhao and D. H. Liu, Bioresour. Technol., 182, $136 \quad$ (2015), https://doi.org/10.1016/j.biortech.2015.01.137

32 A. M. de Castro, M. L. de Albuquerque de Carvalho, S. G. F. Leite and N. Pereira Jr., J. Ind. Microbiol. Biot., 37, 151

(2010), https://doi.org/10.1007/s10295-009-0656-2

33 E. M. Visser, D. L. Falkoski, M. N. de Almeida, G. P. M. Alfenas and V. M. Guimarães, Bioresour. Technol., $\quad 144, \quad 587 \quad$ (2013), https://doi.org/10.1016/j.biortech.2013.07.015

34 L. M. F. Gottschalk, R. A. Oliveira and E. P. da SilvaBon, Biochem. Eng. J., 51, 72 (2010), https://doi.org/10.1016/j.bej.2010.05.003

35 R. R. Singhania, J. K. Saini, R. Saini, M. Adsul, A. Mathur et al., Bioresour. Technol., 169, 490 (2014), https://doi.org/10.1016/j.biortech.2014.07.011 